\title{
Using Different Methods to Produce Vegetative Carob Seedlings
}

\author{
A. S. El-Soda*, A. M. Elhusseiny ${ }^{*}$, A. A. Hammad ${ }^{*}$ and \\ Nagwa I. El-Arabi** \\ Olive \& Semi-arid Zone Fruits Department, Horticulture \\ Research Institute, Agricultural Research Centre and \\ **Department of Genetics, Faculty of Agriculture- Cairo \\ University, Cairo, Egypt.
}

\begin{abstract}
A FIELD experiment was conducted during 2014-2015 to study the influence of different indole butyric acid (IBA) concentration (4000, 6000 and $8000 \mathrm{ppm})$ on rooting of Carob air layers and cuttings at Horticulture Research Institute Egypt, during February, May, August and November. The results indicated that, May is the best time to make air layering. Applying IBA at $4000 \mathrm{ppm}$ had recorded the longest root for genotypes $(1,3$ and 4$)$ in both seasons. IBA at $6000 \mathrm{ppm}$ gave the best percentage of rooting and survival and number of root for genotype (1) and longest root for genotype (5) while, treated with IBA at $8000 \mathrm{ppm}$ registered the highest percentage of rooting and survival also the number of root for genotypes (3- 4 and 5). The percentage of rooting and survival Carob stem cuttings was very low (35 and $51.7 \%$ maximum) respectively. The genetic polymorphism between the four Carob genotypes was detected by RAPD analysis. Twenty eight out of 53 bands detected were polymorphic for the different genotypes. Six RAPD specific markers distinguish genotype 5 followed by genotype 4 (four markers) and both genotypes 1 and 3 showed only two specific markers.
\end{abstract}

Keywords: Carob, Air layering, Rooting, RAPD marker, Indole butyric acid.

Carob (Ceratonia siliqua L.) is a typical tree of the semiarid environments and it grows widely in the Mediterranean basin, and some parts of Western Asia and the Middle East. It produces edible pods that can be used as a fodder in cattle breeding. Carob tolerates harsh conditions such as drought, alkali soils and is extremely tolerant to heat. Therefore, it is used naturally against soil erosion in new reclaimed soils in most Mediterranean areas Janick and Paull (2008). Carob trees can be male, female or hermaphrodite. Commercially, female cultivars are the most important trees to be grown in the groves of the Mediterranean countries Laubscher and Ndakidemi (2008). The morphological and physiological traits of Carob cultivars are often influenced by environmental factors and not able to differentiate very well between the different populations Morsy (2007). The use of molecular markers is mostly contributing to the speeding up of plant breeding and classification, confirming or even reforming the systemic taxonomy of 
several groups of organisms Guzeldag and Çolak (2007). The RAPD analysis was used in semi natural Carob populations from Lebanon. The results showed that the populations did not cluster based on geographic proximity and revealed a significant difference within and between populations, suggesting that the remaining populations constitute a valuable germplasm Talhouk et al. (2005).

Approximately, the annual world production of Carob pods is 214000 tons which is produced mainly in the Mediterranean countries such as Spain (75000t), Italy (30000t), Portugal (45000t), Greece (10000t), Morocco (40000t) and Turkey (14000t) El-Kahkahi et al. (2016). The whole Carob tree components particularly the fruit are useful. High content of sugar and phenol compounds, Carob pulp is used in the human food industry such as the production of alcohol (ethanol), citric acid and cocoa. Additionally, the flour of the pulp can be used as a major component of many foods Makris and Kefalas (2004) and Dakia et al. (2007). The pulp is used in traditional medicine against diarrhea and for the treatment of certain diseases such as gastritis, enteritis, tonsillitis, colds, cancer Gharnit et al. (2004). Gum, i.e. endosperm, remains the most important part of the Carob plant, since it is used as a stabilizer, gelling agent, a fixer in different areas such as food, cosmetics, and pharmaceuticals Biner et al. (2007).

In general, Carob plants can be propagated by different methods including seeds, budding, grafting or cutting Romano et al. (2002). However, Carob seed is difficult to germinate because its coat is extremely hard and does not absorb water Gubbuk et al. (2011). In addition, seedling plants are not true to type and normally result in fruits of varying size and quality Crane and Balerdi (2008). Due to the difficulty to rooting in Carob cuttings by using vegetative reproduction Lee et al. (1977), Hartmann and Kaster (1983), this method is not commercially used Batlle and Tous (1997). Carob grafting takes more than two years to obtain grafted nursery material Batlle and Tous (1997). Therefore, air layering may be a reliable and doable mean of Carob propagation, which is difficult rooting by other methods. Air layering has been applied in economically important woody plants Pio et al. (2007), Gamlath et al. (2010) and Sasso et al. (2010).

Carob propagation by cuttings is difficult to succeed. Until now, there were no any consistent results to be suitable for mass production in commercial nurseries. Therefore, the objective of the present study was to determine the rooting ability of Carob stem cutting and Carob air layering under different indole butyric acid (IBA) concentration and analyzing the genetic diversity among four Egyptian accessions of Carob genotypes by using RAPD markers to establish a correlation between rooting parameters and genetic characterization. 


\section{Materials and Methods}

The present investigation was conducted at the Horticulture Research Institute Egypt, during February, May, August and November 2014 and 2015. The cutting or air layering did not succeed in rooting during February, August and November. In all dates, control treatment had a result (0.00). Therefore, we presented the results of May without control. Four Carob genotypes mature trees $1,3,4$ and 5 (male) that were 5 years old and pod physical characteristics of Carob genotypes 1, 3, and 4 were recorded in Table 1 . The selected trees for this study were vigorous healthy and free from diseases and insect pests.

TABLE 1. Pod physical characteristics of Carob genotypes.

\begin{tabular}{|c|c|c|c|c|c|}
\hline $\begin{array}{c}\text { Number of } \\
\text { genotype }\end{array}$ & $\begin{array}{c}\text { Average } \\
\text { pod weight } \\
(\mathbf{g})\end{array}$ & $\begin{array}{c}\text { Average } \\
\text { pod length } \\
(\mathbf{c m})\end{array}$ & $\begin{array}{c}\text { Average } \\
\text { pod width } \\
(\mathbf{c m})\end{array}$ & $\begin{array}{c}\text { Average pod } \\
\text { thickness(cm) }\end{array}$ & $\begin{array}{c}\text { Seeds/ } \\
\text { pod (\%) }\end{array}$ \\
\hline 1 & 17.52 & 16.00 & 1.26 & 0.59 & 12.10 \\
\hline 3 & 17.28 & 13.83 & 1.14 & 0.62 & 17.00 \\
\hline 4 & 16.29 & 12.80 & 1.00 & 0.62 & 14.00 \\
\hline
\end{tabular}

Each individual plant was considered as a separate block. This investigation included two type of propagation (air layering and stem cutting).

\section{Air layering}

A total of 48 stems were selected from all directions on each healthy tree (approximately $40 \mathrm{~cm}$ long) and 12 stems were air layered per treatment. The leaves around the area, which was to be air-layered, were removed. The stem was girdled by making a cylindrical cut, which was $3.0 \mathrm{~cm}$ in length just below the node to expose the inner woody tissue, and the entire strip of bark was peeled away (Fig 3). Four IBA concentrations 0, 4000, 6000, and 8000 ppm were applied by brush drawing just after removing the barks then covered with moist peat moss then a plastic bag and finally by a piece of aluminum foil and placed around the treated region the entire length of the foil was securely wrapped around the stem. Then covered area gently compressed to remove air, which may penetrate during the covering process (Fig 4). After 20 days, a few shoots were tested for rooting by carefully uncovering the aluminum foil. After 30 days from treatment application, all layering was separated from the mother trees (Fig 5).

\section{Stem cutting}

Carob stem cuttings were taken from the one year old shoot, the cuttings wounded and non-wounded were made of uniform size of $25 \mathrm{~cm}$ long and nearly $1,1.5 \mathrm{~cm}$ thick and having at least five buds and two mature leaves. Cuttings were planted in peat and perlite composed 1:2, V/V and grown in a greenhouse under intermittent mist for 60 days. Misting was applied according to seasonal and daily weather conditions. 


\section{Measurements}

Rooting percentage: computed by the following formula: Percent plant rooting: Total plants rooted/Total plants (100).

Number of roots and root length $(\mathrm{cm})$

Survival percentage (\%): computed by: Percent plant survived: Total plants survived / Total rooted (100) after three months from air layering and four months after planting cutting.

\section{PCR amplification and electrophoresis}

DNA extraction was based on a procedure developed by Porebski et al. (1997) for plants containing high polysaccharide and polyphone components. DNA concentration was determined by running DNA samples on a $1 \%$ agar gel with known concentrations of DNA, ethidium bromide staining, and visual interpretation of band intensity. The polymerase chain reaction was carried out in a Biometric thermal cycler using primers listed in Table 1. The PCR reaction mix includes the following: $10 \mathrm{ng} / \mu \mathrm{L}$ of DNA, $0.5 \mathrm{U}$ of Red Hot Taq polymerase (AB-gene House, UK) and 10-X Taq polymerase buffer (AB-gene House, UK), $10 \mathrm{mMdNTPs}, 50 \mathrm{mM} \mathrm{MgCl} 2,10 \mu \mathrm{M}$ each of forward and reverse primers. The PCR profile starts with $95^{\circ} \mathrm{C}$ for 5 min followed by 35 cycles of denaturation at $94^{\circ} \mathrm{C}$ for $1 \mathrm{~min}$, annealing at 32 for $1 \mathrm{~min}$, extension at $72^{\circ} \mathrm{C}$ for $2 \mathrm{~min}$. A final extension $72^{\circ} \mathrm{C}$ for $7 \mathrm{~min}$ was included. The amplification products were separated in $2 \%(\mathrm{w} / \mathrm{v})$ agar gel in $1 \times \mathrm{x}$ TAE buffer and visualized by staining with Ethidium bromide. Data analysis. The bands were sized and then binary coded by 1 or 0 for their presence or absence in each genotype. The systat ver. 7 (SSPSS inc.c 1997 spss inc. 3/97 standard version) computer programs were used to calculate the pair wise difference matrices Yang and Quiros, (1993).

TABLE 2. The sequence of the RAPD primers used.

\begin{tabular}{|c|c|}
\hline Primer name & Primer sequences $\left(\mathbf{5}^{\prime} \mathbf{- 3}^{\prime}\right)$ \\
\hline OPA-17 & GACCGCTTGT \\
\hline OPA-18 & AGGTGACCGT \\
\hline OPC-01 & TTCGAGCCAG \\
\hline OPC-02 & GTGAGGCGTC \\
\hline OPC -03 & GGGGGTCTTT \\
\hline
\end{tabular}

Statistical analysis

All data were tested for treatments effects on analyzed parameters by the oneway analysis of variance (ANOVA). Difference between treatments were compared by Duncan`s Multiple Range Test, Duncan, (1955), according to Snedecor and Cochran (1980). 


\section{Results and Discussion}

First rooting type: air layering

Rooting percentage (\%)

It is interesting to note in Table 3 that, applying IBA at $6000 \mathrm{ppm}$ to genotype 1 , air layering of carob gave the best significant values of rooting percentage in both seasons. While, the least values were recorded by the highest concentration of IBA in both seasons. Concerning to three genotypes 3, 4 and 5 it can be noted that, rooting percentage increasing with increasing IBA concentration, and the best rooting percentage were achieved by the highest concentration of IBA 8000 ppm in both seasons.

TABLE 3. Effect of IBA concentration on rooting percentage (\%) of Carob air layering during 2014 and 2015 seasons.

\begin{tabular}{|c|c|c|c|c|c|c|c|c|}
\hline \multirow{4}{*}{ Treatments } & \multicolumn{8}{|c|}{ Rooting percentage (\%) } \\
\hline & \multicolumn{4}{|c|}{2014 season } & \multicolumn{4}{|c|}{2015 season } \\
\hline & \multicolumn{4}{|c|}{ Genotype number } & \multicolumn{4}{|c|}{ Genotype number } \\
\hline & 1 & 3 & 4 & 5 male & 1 & 3 & 4 & 5 male \\
\hline $\begin{array}{ll}\text { IBA } & 4000 \\
\text { ppm }\end{array}$ & $\begin{array}{c}82.00 \\
\text { B }\end{array}$ & $\begin{array}{c}73.24 \\
\mathrm{C} \\
\end{array}$ & $\begin{array}{c}87.00 \\
\mathrm{C} \\
\end{array}$ & $\begin{array}{c}95.83 \\
\mathrm{C} \\
\end{array}$ & $\begin{array}{c}80.87 \\
\text { B }\end{array}$ & $\begin{array}{c}75.67 \\
\mathrm{C} \\
\end{array}$ & $\begin{array}{c}89.83 \\
\mathrm{C} \\
\end{array}$ & $\begin{array}{c}95.00 \\
\text { B }\end{array}$ \\
\hline $\begin{array}{ll}\text { IBA } & 6000 \\
\text { ppm }\end{array}$ & $\begin{array}{c}84.17 \\
\mathrm{~A}\end{array}$ & $\begin{array}{c}79.37 \\
\text { B }\end{array}$ & $\begin{array}{c}89.17 \\
\text { B }\end{array}$ & $\begin{array}{c}97.50 \\
\mathrm{~B} \\
\end{array}$ & $\begin{array}{c}85.83 \\
\text { A }\end{array}$ & $\begin{array}{c}77.17 \\
\text { B }\end{array}$ & $\begin{array}{c}90.00 \\
\mathrm{~B}\end{array}$ & $\begin{array}{c}96.67 \\
\text { A }\end{array}$ \\
\hline $\begin{array}{ll}\text { IBA } & 8000 \\
\text { ppm } & \end{array}$ & $\begin{array}{c}76.50 \\
\mathrm{C}\end{array}$ & $\begin{array}{c}81.68 \\
\text { A }\end{array}$ & $\begin{array}{c}90.77 \\
\text { A }\end{array}$ & $\begin{array}{c}98.33 \\
\text { A }\end{array}$ & $\begin{array}{c}79.17 \\
\mathrm{C}\end{array}$ & $\begin{array}{c}82.49 \\
\text { A }\end{array}$ & $\begin{array}{c}93.33 \\
\mathrm{~A}\end{array}$ & $\begin{array}{c}97.50 \\
\text { A }\end{array}$ \\
\hline
\end{tabular}

Means designated with the same letter(s) in the same column are not significantly different at 0.05 level of probability

\section{Number of roots}

Number of roots was affected significantly by increasing the concentration of IBA from $4000 \mathrm{ppm}$ to $8000 \mathrm{ppm}$ for all genotypes except genotype 1 in both seasons (Table 4). Concerning to genotype 1, IBA at $6000 \mathrm{ppm}$ gave the highest number of roots in both seasons then IBA at $4000 \mathrm{ppm}$ followed by the highest concentration of IBA $8000 \mathrm{ppm}$. Referring to genotypes 3, 4, 5, IBA at $8000 \mathrm{ppm}$ had recorded the highest number of roots in both seasons. On the other hand, the lowest number of roots was achieved by lowest concentration of IBA 4000 ppm.

\section{Root length $(\mathrm{cm})$}

In Table 5 data appeared that, in both seasons of study the highest significant value of root length for genotype 1, 3, 4 were recorded by lowest concentration of IBA $4000 \mathrm{ppm}$. While, the highest root length of genotype 5 was observed by IBA at 6000 in the first season. In addition, both concentration of IBA $6000-$ 8000 ppm gave the same analogous effect in the second season. 
TABLE 4. Effect of different IBA concentration on number of roots of Carob air layering during 2014 and 2015 seasons.

\begin{tabular}{|c|c|c|c|c|c|c|c|c|}
\hline \multirow{4}{*}{ Treatments } & \multicolumn{8}{|c|}{ Number of roots } \\
\hline & \multirow{2}{*}{\multicolumn{4}{|c|}{$\begin{array}{c}2014 \text { season } \\
\text { Genotype number }\end{array}$}} & \multirow{2}{*}{\multicolumn{4}{|c|}{$\begin{array}{c}2015 \text { season } \\
\text { Genotype number }\end{array}$}} \\
\hline & & & & & & & & \\
\hline & 1 & 3 & 4 & $\begin{array}{c}\mathbf{5} \\
(\mathrm{male}) \\
\end{array}$ & 1 & 3 & 4 & $\begin{array}{c}5 \\
\text { (male) } \\
\end{array}$ \\
\hline $\begin{array}{l}\text { IBA } 4000 \\
\text { ppm }\end{array}$ & $\begin{array}{c}18.50 \\
\mathrm{~B}\end{array}$ & $\begin{array}{c}3.40 \\
\mathrm{C}\end{array}$ & $\begin{array}{c}15.40 \\
\mathrm{C}\end{array}$ & $\begin{array}{c}8.50 \\
\mathrm{C}\end{array}$ & $\begin{array}{c}19.20 \\
\mathrm{~B}\end{array}$ & $\begin{array}{c}4.23 \\
\mathrm{C}\end{array}$ & $\begin{array}{c}17.33 \\
\mathrm{C}\end{array}$ & $\begin{array}{c}9.21 \\
\mathrm{C}\end{array}$ \\
\hline $\begin{array}{l}\text { IBA } 6000 \\
\text { ppm }\end{array}$ & $\begin{array}{c}22.70 \\
\mathrm{~A}\end{array}$ & $\begin{array}{c}9.30 \\
\mathrm{~B}\end{array}$ & $\begin{array}{c}22.00 \\
\mathrm{~B}\end{array}$ & $\begin{array}{c}12.55 \\
\mathrm{~B}\end{array}$ & $\begin{array}{c}24.20 \\
\mathrm{~A}\end{array}$ & $\begin{array}{c}8.20 \\
\mathrm{~B}\end{array}$ & $\begin{array}{l}21.40 \\
\mathrm{~B}\end{array}$ & $\begin{array}{c}12.18 \\
\mathrm{~B}\end{array}$ \\
\hline $\begin{array}{l}\text { IBA } 8000 \\
\text { ppm }\end{array}$ & $\begin{array}{c}4.00 \\
\mathrm{C}\end{array}$ & $\begin{array}{c}11.60 \\
\mathrm{~A}\end{array}$ & $\begin{array}{c}26.20 \\
\mathrm{~A}\end{array}$ & $\begin{array}{c}20.87 \\
\text { A }\end{array}$ & $\begin{array}{c}4.23 \\
\mathrm{C}\end{array}$ & $\begin{array}{c}12.10 \\
\mathrm{~A}\end{array}$ & $\begin{array}{c}25.40 \\
\mathrm{~A}\end{array}$ & $\begin{array}{c}21.47 \\
\mathrm{~A}\end{array}$ \\
\hline
\end{tabular}

Means designated with the same letter(s) in the same column are not significantly different at 0.05 level of probability

TABLE 5. Effect of IBA concentration on root length $(\mathrm{cm})$ of Carob air layering during 2014 and 2015 seasons.

\begin{tabular}{|l|c|c|c|c|c|c|c|c|}
\hline & \multicolumn{8}{|c|}{ Survival percentage (\%) } \\
\cline { 2 - 9 } Treatments & \multicolumn{4}{|c|}{ 2014 season } & \multicolumn{5}{c|}{ 2015 season } \\
\cline { 2 - 9 } & $\mathbf{1}$ & $\mathbf{3}$ & $\mathbf{4}$ & $\mathbf{5}$ & $\mathbf{1}$ & $\mathbf{3}$ & $\mathbf{4}$ & $\mathbf{5}$ \\
& & & & male & & & & male \\
\hline IBA 4000 & 90.10 & 85.27 & 95.14 & 96.52 & 87.20 & 83.48 & 94.37 & 97.81 \\
ppm & $\mathrm{B}$ & $\mathrm{C}$ & $\mathrm{B}$ & $\mathrm{B}$ & $\mathrm{B}$ & $\mathrm{C}$ & $\mathrm{C}$ & $\mathrm{B}$ \\
\hline IBA 6000 & 91.78 & 88.28 & 96.36 & 97.35 & 91.36 & 87.37 & 95.20 & 98.10 \\
ppm & $\mathrm{A}$ & $\mathrm{B}$ & $\mathrm{A}$ & $\mathrm{B}$ & $\mathrm{A}$ & $\mathrm{B}$ & $\mathrm{B}$ & $\mathrm{B}$ \\
\hline IBA 8000 & 83.00 & 89.90 & 96.91 & 99.66 & 82.00 & 88.29 & 98.77 & 99.37 \\
ppm & $\mathrm{C}$ & $\mathrm{A}$ & $\mathrm{A}$ & $\mathrm{A}$ & $\mathrm{C}$ & $\mathrm{A}$ & $\mathrm{A}$ & $\mathrm{A}$ \\
\hline
\end{tabular}

Means designated with the same letter(s) in the same column are not significantly different at 0.05 level of probability

\section{Survival percentage (\%)}

Data in Table 6 revealed that, when Carob air layering treated with IBA at $6000 \mathrm{ppm}$, the survival percentage of genotype 1 recorded the best significant values in both seasons. On the other hand, IBA at $8000 \mathrm{ppm}$ had the lowest percentage of survival. Regarding to genotypes 3,4 and 5, it can be explained that, with IBA concentration increased, the percentage of survival increased in both seasons. Whereas, the treatment of IBA at $8000 \mathrm{ppm}$ had the highest significant values. While, the least values were observed by IBA treatment at 4000ppm.

These results may be led to the conclusion that, May was considered the best date to make Carob air layering compared to other three dates (November, February, August), which did not succeed in rooting. Additionally, applying IBA

Egypt. J. Hort. Vol. 43, No.2 (2016) 
encouraged rooting of Carob air layering after one month. While, without treated by any rooting hormone Gubbuk et al. (2011) found that, Carob air layering succeed in rooting after six months. IBA treatments improved rooting and survival percentage Das et al. (2014) on litchi. Higher rooting and survival percentage might be due to optimum IBA concentration may have caused mobilization and utilization of carbohydrates and nitrogen fraction with the presence of co-factor at wound site, which may have helped in better root initiation Chawla et al. (2012). Also, Lopes et al. (2005) on cashew and Chawla et al. (2012) and Das \& Prasad (2014) on litchi they illustrated that the highest average number and length of roots were observed with highest concentration of IBA. These could be explained that accelerated rooting in air layering with the increased IBA concentration might be due to increased cell wall elasticity, which further may have accelerated cell division and in turn increased number of roots up to certain level. This might be due to increasing in carbohydrate and metabolic activities Bora et al. (2006). Furthermore, IBA promotes root length by influencing the synthesis of enzymes, which are concerned with the cell enlargement, the enzymes involved in cell enlargement process are triggered by the auxin at higher concentration Singh et al. (2009).

TABLE 6. Effect of IBA concentration on survival percentage (\%) of Carob air layering during 2014 and 2015 seasons.

\begin{tabular}{|c|c|c|c|c|c|c|c|c|}
\hline \multirow{4}{*}{ Treatments } & \multicolumn{8}{|c|}{ Root length (cm) } \\
\hline & \multicolumn{4}{|c|}{2014 season } & \multicolumn{4}{|c|}{2015 season } \\
\hline & \multicolumn{4}{|c|}{ Genotype number } & \multicolumn{4}{|c|}{ Genotype number } \\
\hline & 1 & 3 & 4 & $\begin{array}{c}\mathbf{5} \\
\text { (male) }\end{array}$ & 1 & 3 & 4 & $\begin{array}{c}\mathbf{5} \\
\text { (male) }\end{array}$ \\
\hline $\begin{array}{l}\text { IBA } 4000 \\
\text { ppm }\end{array}$ & $\begin{array}{c}11.51 \\
\mathrm{~A}\end{array}$ & $\begin{array}{c}12.63 \\
\mathrm{~A}\end{array}$ & $\begin{array}{c}21.45 \\
\mathrm{~A}\end{array}$ & $\begin{array}{c}7.20 \\
\mathrm{C}\end{array}$ & $\begin{array}{c}11.03 \\
\mathrm{~A}\end{array}$ & $\begin{array}{c}13.30 \\
\mathrm{~A}\end{array}$ & $\begin{array}{c}21.20 \\
\mathrm{~A}\end{array}$ & $\begin{array}{c}7.50 \\
\mathrm{~B}\end{array}$ \\
\hline $\begin{array}{l}\text { IBA } 6000 \\
\text { ppm }\end{array}$ & $\begin{array}{c}6.75 \\
\mathrm{~B} \\
\end{array}$ & $\begin{array}{c}10.90 \\
\mathrm{~B}\end{array}$ & $\begin{array}{c}14.00 \\
\mathrm{~B}\end{array}$ & $\begin{array}{c}12.40 \\
\mathrm{~A}\end{array}$ & $\begin{array}{c}7.00 \\
B\end{array}$ & $\begin{array}{c}10.17 \\
\mathrm{~B}\end{array}$ & $\begin{array}{c}15.23 \\
\mathrm{~B}\end{array}$ & $\begin{array}{c}13.00 \\
\mathrm{~A}\end{array}$ \\
\hline $\begin{array}{l}\text { IBA } 8000 \\
\text { ppm }\end{array}$ & $\begin{array}{c}1.70 \\
\mathrm{C} \\
\end{array}$ & $\begin{array}{c}3.15 \\
\mathrm{C}\end{array}$ & $\begin{array}{c}14.31 \\
\mathrm{~B}\end{array}$ & $\begin{array}{c}11.57 \\
\mathrm{~B}\end{array}$ & $\begin{array}{c}1.50 \\
\mathrm{C} \\
\end{array}$ & $\begin{array}{c}3.13 \\
\mathrm{C}\end{array}$ & $\begin{array}{c}15.13 \\
\mathrm{~B}\end{array}$ & $\begin{array}{c}12.00 \\
\mathrm{~A}\end{array}$ \\
\hline
\end{tabular}

Means designated with the same letter(s) in the same column are not significantly different at 0.05 level of probability

Second rooting type: stem cutting

Rooting percentage (\%)

The best rooting percentage values for genotype 1 (Table 7) were recorded by IBA treatment at $6000 \mathrm{ppm}$ and wounding in both seasons. IBA at $8000 \mathrm{ppm}$ and wounding gave the best results of rooting percentage for genotypes 3, 4 and 5 . While, the least values of rooting percentage for all treatments were revealed by the lowest IBA concentration in both seasons.

Number of roots

Generally, it can be noted from Table 8 that the highest significant number of root of Carob cutting by genotype 1 (7.31 and 7.00) in the first season and (7.87

Egypt. J. Hort. Vol. 43, No.2 (2016) 
and 7.63) in the second season took place with the IBA at $6000 \mathrm{ppm}$ and wounding and IBA at $8000 \mathrm{ppm}$ and wounding respectively followed by IBA at $4000 \mathrm{ppm}$ and wounding and IBA at $6000 \mathrm{ppm}$. While, the lowest number of roots (1.88 and 1.63) was resulted from IBA at $8000 \mathrm{ppm}$ treatment. Concerning to genotype 3 , treated cutting by IBA at $8000 \mathrm{ppm}$ and wounding had the highest number of root (4.00 and 4.77) in both seasons. The lowest number of root was noticed by IBA at $4000 \mathrm{ppm}$. Results of genotype 4 showed that IBA at 6000 ppm and wounding recorded the highest number of roots $(5.24-5.64)$ in both seasons. In case of genotype (5), wounding cutting and IBA at $4000 \mathrm{ppm}$ or wounding cutting and IBA at 6000 ppm or wounding cutting and IBA at 8000 ppm had the highest number of root compared with other treatments.

TABLE 7. Effect of IBA concentration and wounding on rooting percentage (\%) of carob stem cutting during 2014 and 2015 seasons

\begin{tabular}{|c|c|c|c|c|c|c|c|c|}
\hline \multirow{4}{*}{ Treatments } & \multicolumn{8}{|c|}{ Rooting percentage (\%) } \\
\hline & \multirow{2}{*}{\multicolumn{4}{|c|}{$\begin{array}{c}2014 \text { season } \\
\text { Genotype number }\end{array}$}} & \multirow{2}{*}{\multicolumn{4}{|c|}{$\begin{array}{c}2015 \text { season } \\
\text { Genotype number }\end{array}$}} \\
\hline & & & & & & & & \\
\hline & 1 & 3 & 4 & 5 male & 1 & 3 & 4 & 5 male \\
\hline \multirow{2}{*}{ IBA $4000 \mathrm{ppm}$} & 10.31 & 14.16 & 8.50 & 16.28 & 11.30 & 13.61 & 9.63 & 15.10 \\
\hline & $\mathrm{E}$ & $\mathrm{F}$ & $\mathrm{F}$ & $\mathrm{E}$ & $\mathrm{E}$ & $\mathrm{F}$ & $\mathrm{F}$ & $\mathrm{F}$ \\
\hline \multirow{2}{*}{$\begin{array}{l}\text { IBA } 4000 \mathrm{ppm} \\
\text { +wounding }\end{array}$} & 18.50 & 15.28 & 18.72 & 18.16 & 16.93 & 16.15 & 17.41 & 16.87 \\
\hline & $\mathrm{D}$ & E & E & $\mathrm{D}$ & $\mathrm{D}$ & $\mathrm{E}$ & E & $\mathrm{E}$ \\
\hline \multirow{2}{*}{ IBA 6000 ppm } & 25.33 & 20.67 & 23.61 & 22.06 & 24.86 & 22.37 & 23.12 & 23.49 \\
\hline & $\mathrm{B}$ & $\mathrm{D}$ & $\mathrm{D}$ & $\mathrm{C}$ & $\mathrm{B}$ & $\mathrm{D}$ & $\mathrm{D}$ & $\mathrm{D}$ \\
\hline \multirow{2}{*}{$\begin{array}{l}\text { IBA } 6000 \mathrm{ppm} \\
\text { + wounding }\end{array}$} & 30.06 & 25.94 & 27.39 & 25.66 & 32.15 & 27.74 & 29.40 & 26.31 \\
\hline & A & $\mathrm{C}$ & B & B & A & $\mathrm{C}$ & $\mathrm{B}$ & B \\
\hline \multirow{2}{*}{ IBA 8000 ppm } & 17.78 & 32.33 & 25.22 & 25.31 & 18.32 & 33.79 & 26.42 & 24.55 \\
\hline & D & B & $\mathrm{C}$ & B & D & B & $\mathrm{C}$ & $\mathrm{C}$ \\
\hline \multirow{2}{*}{$\begin{array}{l}\text { IBA } 8000 \text { ppm } \\
\text { + wounding }\end{array}$} & 19.56 & 35.00 & 31.17 & 31.50 & 20.64 & 34.81 & 30.70 & 32.32 \\
\hline & $\mathrm{C}$ & A & A & A & $\mathrm{C}$ & A & A & A \\
\hline
\end{tabular}

Means designated with the same letter(s) in the same column are not significantly different at 0.05 level of probability.

\section{Root length $(\mathrm{cm})$}

According to root length $(\mathrm{cm})$, data in Table 9 revealed that the highest significant root length $(6.30$ and $6.53 \mathrm{~cm})$ resulted from genotype 1 cutting treated by IBA at $4000 \mathrm{ppm}$ and wounding followed by IBA at $6000 \mathrm{ppm}$ and wounding $(5.40$ and $5.67 \mathrm{~cm})$ then IBA at $8000 \mathrm{ppm}$ and wounding $(4.30$ and $4.47 \mathrm{~cm}$ ). Treated genotype 3 cutting with IBA at $8000 \mathrm{ppm}$ or IBA at 8000 and wounding gave the longest root $(2.80-2.87 \mathrm{~cm})$ and $(3.03-3.40 \mathrm{~cm})$ during 2014 and 2015 seasons respectively followed by IBA at 6000 and wounding. Carob stem cutting of genotypes 4 and 5, which treated with IBA at 4000 and wounding gave the longest root in both seasons.

Egypt. J. Hort. Vol. 43, No.2 (2016) 
TABLE 8. Effect of IBA concentration and wounding on number of roots of Carob stem cutting during 2014 and 2015 seasons.

\begin{tabular}{|c|c|c|c|c|c|c|c|c|}
\hline \multirow{4}{*}{ Treatments } & \multicolumn{8}{|c|}{ Number of root } \\
\hline & \multicolumn{4}{|c|}{2014 season } & \multicolumn{4}{|c|}{2015 season } \\
\hline & \multicolumn{4}{|c|}{ Genotype number } & \multicolumn{4}{|c|}{ Genotype number } \\
\hline & 1 & 3 & 4 & $\begin{array}{c}\mathbf{5} \\
\text { (male) }\end{array}$ & 1 & 3 & 4 & $\begin{array}{c}\mathbf{5} \\
(\text { male }) \\
\end{array}$ \\
\hline \multirow{2}{*}{ IBA 4000 ppm } & 3.52 & 1.25 & 2.10 & 2.00 & 3.37 & 0.35 & 1.72 & 2.30 \\
\hline & $\mathrm{C}$ & $\mathrm{D}$ & $\mathrm{D}$ & $\mathrm{C}$ & $\mathrm{C}$ & $\mathrm{D}$ & $\mathrm{D}$ & $\mathrm{C}$ \\
\hline \multirow{2}{*}{$\begin{array}{l}\text { IBA } 4000 \mathrm{ppm} \\
\text { +wounding }\end{array}$} & 5.08 & 1.50 & 3.06 & 4.67 & 5.33 & 0.38 & 3.62 & 6.00 \\
\hline & $\mathrm{B}$ & $\mathrm{D}$ & $\mathrm{B}$ & $\mathrm{A}$ & $\mathrm{B}$ & $\mathrm{D}$ & $\mathrm{B}$ & $\mathrm{A}$ \\
\hline \multirow{2}{*}{ IBA 6000 ppm } & 5.00 & 2.16 & 3.12 & 2.06 & 5.67 & 1.69 & 3.36 & 2.60 \\
\hline & $\mathrm{B}$ & $\mathrm{C}$ & $\mathrm{B}$ & $\mathrm{C}$ & $\mathrm{B}$ & $\mathrm{C}$ & $\mathrm{B}$ & $\mathrm{C}$ \\
\hline \multirow{2}{*}{$\begin{array}{l}\text { IBA } 6000 \mathrm{ppm} \\
+ \text { wounding }\end{array}$} & 7.31 & 3.00 & 5.24 & 4.43 & 7.87 & 3.30 & 5.64 & 5.86 \\
\hline & $\mathrm{A}$ & $\mathrm{B}$ & $\mathrm{A}$ & $\mathrm{A}$ & $\mathrm{A}$ & $\mathrm{B}$ & $\mathrm{A}$ & $\mathrm{A}$ \\
\hline \multirow{2}{*}{ IBA 8000 ppm } & 1.88 & 3.17 & 2.47 & 3.51 & 1.63 & 3.53 & 2.35 & 3.43 \\
\hline & $\mathrm{D}$ & $\mathrm{B}$ & $\mathrm{C}$ & $\mathrm{B}$ & $\mathrm{D}$ & $\mathrm{B}$ & $\mathrm{C}$ & $\mathrm{B}$ \\
\hline \multirow{2}{*}{$\begin{array}{l}\text { IBA } 8000 \mathrm{ppm} \\
+ \text { wounding }\end{array}$} & 7.00 & 4.00 & 3.20 & 4.30 & 7.63 & 4.77 & 3.21 & 5.81 \\
\hline & $\mathrm{A}$ & $\mathrm{A}$ & $\mathrm{B}$ & $\mathrm{A}$ & $\mathrm{A}$ & A & $\mathrm{B}$ & A \\
\hline
\end{tabular}

Means designated with the same letter(s) in the same column are not significantly different at 0.05 level of probability.

TABLE 9. Effect of IBA concentration and wounding on root length $(\mathrm{cm})$ of Carob stem cutting during 2014 and 2015 seasons.

\begin{tabular}{|c|c|c|c|c|c|c|c|c|}
\hline \multirow{4}{*}{ Treatments } & \multicolumn{8}{|c|}{ Root length $(\mathrm{cm})$} \\
\hline & \multicolumn{4}{|c|}{2014 season } & \multicolumn{4}{|c|}{2015 season } \\
\hline & \multicolumn{4}{|c|}{ Genotype number } & \multicolumn{4}{|c|}{ Genotype number } \\
\hline & $\mathbf{1}$ & 3 & 4 & 5 Male & 1 & 3 & 4 & 5 male \\
\hline \multirow{2}{*}{ IBA 4000 ppm } & 2.50 & 0.90 & 2.25 & 3.60 & 2.67 & 0.50 & 1.51 & 3.87 \\
\hline & $\mathrm{D}$ & $\mathrm{D}$ & $\mathrm{E}$ & $\mathrm{D}$ & $\mathrm{D}$ & $\mathrm{D}$ & $\mathrm{E}$ & $\mathrm{C}$ \\
\hline \multirow{2}{*}{$\begin{array}{l}\text { IBA } 4000 \mathrm{ppm} \\
\text { +wounding }\end{array}$} & 6.30 & 1.03 & 7.08 & 6.20 & 6.53 & 0.67 & 7.23 & 7.10 \\
\hline & A & $\mathrm{D}$ & A & A & A & $\mathrm{D}$ & A & A \\
\hline \multirow{2}{*}{ IBA 6000 ppm } & 4.10 & 1.70 & 6.00 & 3.23 & 4.43 & 1.80 & 6.13 & 3.27 \\
\hline & $\mathrm{C}$ & $\mathrm{C}$ & $\mathrm{B}$ & $\mathrm{E}$ & $\mathrm{C}$ & $\mathrm{C}$ & B & D \\
\hline \multirow{2}{*}{$\begin{array}{l}\text { IBA } 6000 \text { ppm } \\
\text { + wounding }\end{array}$} & 5.40 & 2.42 & 3.50 & 4.50 & 5.67 & 2.60 & 3.73 & 4.57 \\
\hline & B & B & $\mathrm{D}$ & $\mathrm{C}$ & $\mathrm{B}$ & $\mathrm{B}$ & $\mathrm{D}$ & B \\
\hline \multirow{2}{*}{ IBA 8000 ppm } & 1.20 & 2.80 & 3.80 & 3.19 & 2.03 & 3.03 & 3.97 & 3.33 \\
\hline & $\mathrm{E}$ & $\mathrm{AB}$ & $\mathrm{D}$ & $\mathrm{E}$ & $\mathrm{E}$ & $\mathrm{AB}$ & $\mathrm{CD}$ & $\mathrm{D}$ \\
\hline \multirow{2}{*}{$\begin{array}{l}\text { IBA } 8000 \mathrm{ppm} \\
\text { + wounding }\end{array}$} & 4.30 & 2.87 & 4.20 & 5.70 & 4.47 & 3.40 & 4.33 & 6.80 \\
\hline & $\mathrm{C}$ & A & $\mathrm{C}$ & B & $\mathrm{C}$ & A & $\mathrm{C}$ & A \\
\hline
\end{tabular}

Means designated with the same letter(s) in the same column are not significantly different at 0.05 level of probability.

Survival percentage (\%)

It could be summarized that genotype 1 cutting treated by IBA at $6000 \mathrm{ppm}$ and wounding recorded the highest significant percentage of cutting survival in both seasons (Table 10). The opposite results were obtained with the least concentration of IBA. According to genotype 3, 4 and 5, the best treatment in both seasons, which gave the highest percentage of survival, was IBA at 8000 ppm and wounding. 
Our results showed the Carob stem cutting had poor rooting, number and length of roots. These results are confirmed with the results obtained by Lee et al. (1977) and Hartmann \& Kester (1983) they mentioned that Carob is very difficult to root and its adventitious rooting potential is low. Applying IBA to Carob stem cutting enhancing rooting percentage, number of root and root length Mohamed (1980), AlTury et al. (1999), Shaheen \& Aly (2011) and Zaen El-Deen (2014). It can explain low rooting percentage may be due to little or lack of naturally occurring substances that appear to act synergistically with indole acetic acid in promoting rooting. Hess (1962) termed these non-auxin rooting stimuli rooting co-factor.

TABLE 10. Effect of IBA concentration and wounding on survival percentage of carob stem cutting during 2014 and 2015 seasons.

\begin{tabular}{|c|c|c|c|c|c|c|c|c|}
\hline \multirow{4}{*}{ Treatments } & \multicolumn{8}{|c|}{ Survival rooting $(\%)$} \\
\hline & \multirow{2}{*}{\multicolumn{4}{|c|}{$\begin{array}{c}2014 \text { season } \\
\text { Genotype number }\end{array}$}} & \multirow{2}{*}{\multicolumn{4}{|c|}{$\begin{array}{c}2015 \text { season } \\
\text { Genotype number }\end{array}$}} \\
\hline & & & & & & & & \\
\hline & 1 & 3 & 4 & 5 male & 1 & 3 & 4 & 5 male \\
\hline $\begin{array}{l}\text { IBA } 4000 \\
\text { ppm }\end{array}$ & $\begin{array}{c}19.54 \\
F\end{array}$ & $\begin{array}{c}31.44 \\
\mathrm{E}\end{array}$ & $\begin{array}{c}12.87 \\
F\end{array}$ & $\begin{array}{c}24.10 \\
\mathrm{E}\end{array}$ & $\begin{array}{c}20.36 \\
F\end{array}$ & $\begin{array}{c}33.64 \\
\mathrm{E}\end{array}$ & $\begin{array}{c}10.98 \\
F\end{array}$ & $\begin{array}{c}23.94 \\
\mathrm{E}\end{array}$ \\
\hline $\begin{array}{l}\text { IBA } 4000 \\
\text { ppm } \\
\text { +wounding }\end{array}$ & $\begin{array}{c}30.03 \\
\mathrm{E}\end{array}$ & $\begin{array}{l}35.75 \\
\mathrm{D}\end{array}$ & $\begin{array}{c}29.67 \\
\mathrm{E}\end{array}$ & $\begin{array}{l}32.36 \\
\mathrm{D}\end{array}$ & $\begin{array}{c}29.15 \\
\mathrm{E}\end{array}$ & $\begin{array}{l}36.22 \\
\mathrm{D}\end{array}$ & $\begin{array}{c}30.19 \\
\mathrm{E}\end{array}$ & $\begin{array}{c}30.69 \\
\mathrm{D}\end{array}$ \\
\hline $\begin{array}{l}\text { IBA } 6000 \\
\text { ppm }\end{array}$ & $\begin{array}{c}38.00 \\
\mathrm{~B}\end{array}$ & $\begin{array}{c}36.36 \\
\mathrm{D}\end{array}$ & $\begin{array}{l}35.00 \\
\mathrm{D}\end{array}$ & $\begin{array}{c}35.13 \\
\mathrm{C}\end{array}$ & $\begin{array}{c}38.42 \\
\mathrm{~B}\end{array}$ & $\begin{array}{c}37.89 \\
\mathrm{D}\end{array}$ & $\begin{array}{l}36.44 \\
\mathrm{D}\end{array}$ & $\begin{array}{c}34.73 \\
\mathrm{C}\end{array}$ \\
\hline $\begin{array}{l}\text { IBA } 6000 \\
\text { ppm }+ \\
\text { wounding }\end{array}$ & $\begin{array}{c}41.55 \\
\mathrm{~A}\end{array}$ & $\begin{array}{l}38.91 \\
\mathrm{C}\end{array}$ & $\begin{array}{c}39.14 \\
\text { B }\end{array}$ & $\begin{array}{c}42.38 \\
B\end{array}$ & $\begin{array}{c}42.21 \\
\mathrm{~A}\end{array}$ & $\begin{array}{c}39.23 \\
\mathrm{C}\end{array}$ & $\begin{array}{c}39.82 \\
\mathrm{~B}\end{array}$ & $\begin{array}{c}43.88 \\
\mathrm{~A}\end{array}$ \\
\hline $\begin{array}{l}\text { IBA } 8000 \\
\text { ppm }\end{array}$ & $\begin{array}{l}32.25 \\
\mathrm{D}\end{array}$ & $\begin{array}{c}42.83 \\
\mathrm{~B}\end{array}$ & $\begin{array}{c}38.05 \\
\mathrm{C}\end{array}$ & $\begin{array}{c}34.27 \\
\mathrm{C}\end{array}$ & $\begin{array}{c}30.42 \\
D\end{array}$ & $\begin{array}{c}44.56 \\
\text { B }\end{array}$ & $\begin{array}{c}37.60 \\
\mathrm{C}\end{array}$ & $\begin{array}{c}35.85 \\
\mathrm{~B}\end{array}$ \\
\hline $\begin{array}{l}\text { IBA } 8000 \\
\text { ppm }+ \\
\text { wounding }\end{array}$ & $\begin{array}{c}34.00 \\
\mathrm{C}\end{array}$ & $\begin{array}{c}51.70 \\
\mathrm{~A}\end{array}$ & $\begin{array}{c}44.56 \\
\mathrm{~A}\end{array}$ & $\begin{array}{c}43.86 \\
\mathrm{~A}\end{array}$ & $\begin{array}{c}36.61 \\
\mathrm{C}\end{array}$ & $\begin{array}{c}49.42 \\
\text { A }\end{array}$ & $\begin{array}{c}43.77 \\
\text { A }\end{array}$ & $\begin{array}{c}45.60 \\
\mathrm{~A}\end{array}$ \\
\hline
\end{tabular}

Means designated with the same letter(s) in the same column are not significantly different at 0.05 level of probability.

\section{DNA fingerprint}

In order to study the genetic difference among the four Carob genotypes, DNA samples were subjected to RAPD analysis. All of the 5 primers produced reproducible PCR products with a clear pattern for each genotype and showing informative and easily scrabble RAPD profiles. In this study, a total of 53 alleles were detected among the four carob genotypes (Table 11 and Fig.1). Only 28 of them were polymorphic markers $(52.8 \%)$. The highest number of bands (16 bands) was generated by using the primer OPC-03, while the lowest one was four bands and generated with primer OPC-01. The highest polymorphism percentages belonged to marker OPC-02 (100\%) followed by OPC-01 $(75 \%)$ then OPA-18 (42.8\%) then OPA-17 (37.5), while the lowest belonged to marker OPC-03 $(31.25 \%)$. Fourteen out of the 28 polymorphic RAPD markers were found to be genotype specific (50\%). Therefore, this RAPD marker can be used as associated marker for the Carob genotype. Six RAPD specific markers distinguish genotype 5 that showed the high rooting air layering percentage

Egypt. J. Hort. Vol. 43, No.2 (2016) 
$(98.33 \%)$, root length $(5.70 \mathrm{~cm})$ and survival percentage $(99.66 \%)$ by using IBA at $8000 \mathrm{ppm}$. The all six markers were positive unique bands using OPA-17 (462 and $650 \mathrm{bp})$, OPC-02 (327, 457 and $890 \mathrm{bp})$ and OPA-18 (240 bp). Genotype 4 showed four specific markers one positive using OPC-02 (431 bp) and three negative using OPC-01 (355, 430 and $477 \mathrm{bp})$. The results showed that genotype 4 was the highest genotypes in number of root $(26.2)$ and root length $(15.13 \mathrm{~cm})$ by using IBA at $8000 \mathrm{ppm}$. Both genotypes 1 and 2 showed only two specific unique bands (Table 12). The RAPD data was used to design the dendrogram of the four Carob genotypes (Fig. 2). The cluster analysis indicates that the accessions of Carob were grouped roughly into two highly distant groups, one minor group having genotype 5 only and one major group containing all the other accessions that divided into sub-cluster contain genotypes 2 and 3 together.

TABLE 11. Total number of scorable alleles and the allelic polymorphic among Carob genotypes.

\begin{tabular}{|c|c|c|c|c|c|}
\hline $\begin{array}{c}\text { Primer } \\
\text { name }\end{array}$ & $\begin{array}{c}\text { Total no. } \\
\text { of alleles }\end{array}$ & $\begin{array}{c}\text { Polymor- } \\
\text { phic alleles }\end{array}$ & $\begin{array}{c}\text { Polymor- } \\
\text { phism \% }\end{array}$ & $\begin{array}{c}\text { Monomor } \\
\text { phic alleles }\end{array}$ & $\begin{array}{c}\text { Monophor } \\
\text { phic \% }\end{array}$ \\
\hline OPA-17 & 8 & 3 & 37.5 & 5 & 62.5 \\
\hline OPA-18 & 14 & 6 & 42.8 & 8 & 57.14 \\
\hline OPC-01 & 4 & 3 & 75 & 1 & 25 \\
\hline OPC-02 & 11 & 11 & 100 & Zero & Zero \\
\hline OPC -03 & 16 & 5 & 31.25 & 11 & 68.75 \\
\hline Total & $\mathbf{5 3}$ & $\mathbf{2 8}$ & $\mathbf{5 2 . 8}$ & $\mathbf{2 5}$ & $\mathbf{4 7 . 1 6}$ \\
\hline
\end{tabular}

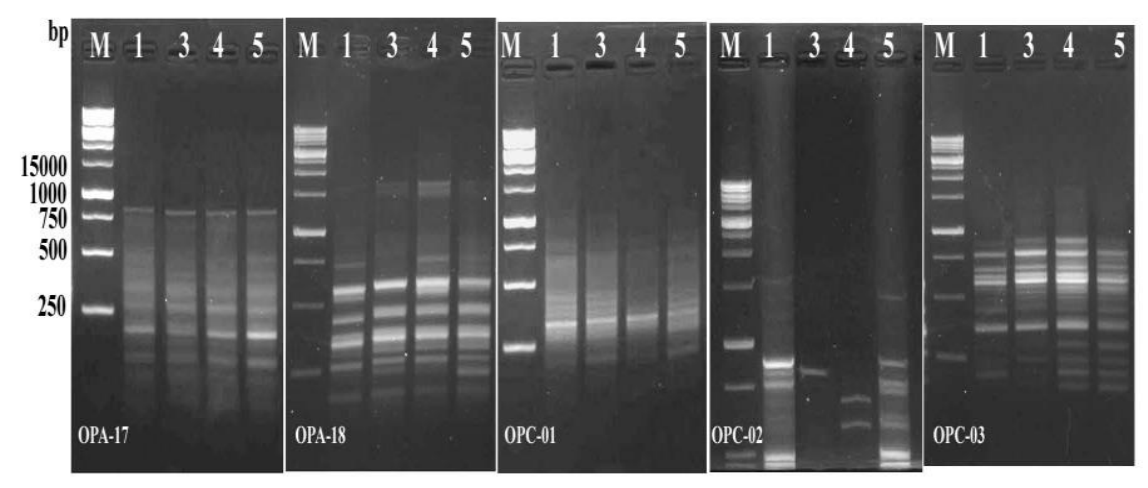

Fig. 1. RAPD profile demonstrating polymorphism among the five Carob genotypes, $M$ refers to DNA marker of $1 \mathrm{~Kb}$ ladder. Lanes 1-5 represent different CAROB strains. 
TABLE 12. Carob genotypes specific RAPD markers .

\begin{tabular}{|c|c|c|c|c|}
\hline Cultivar & \multicolumn{3}{|c|}{ RAPD markers } & \\
\hline & \multicolumn{2}{|l|}{ Positive } & Negative & \\
\hline 1 & \multicolumn{2}{|c|}{ OPC-02 (1033 bp) } & OPC-03 (426bp) & 2 \\
\hline 3 & \multicolumn{2}{|c|}{ OPA-18 (270 bp) } & OPA-18 (739bp) & 2 \\
\hline 4 & \multicolumn{2}{|c|}{ OPC-02 (431bp), } & $\begin{array}{l}\text { OPC-01 (477, } \\
430 \text { and } 355 b p)\end{array}$ & 4 \\
\hline 5 & $\begin{array}{l}\text { OPA-17 } \\
\text { (462 and } \\
650 \mathrm{bp}), \\
\text { OPA-18 } \\
(240 \mathrm{bp}), \\
\text { OPC-02 } \\
(327,457 \\
\text { and } 890 \mathrm{bp})\end{array}$ & ------------------- & 6 & \\
\hline Total & & & 14 & \\
\hline
\end{tabular}

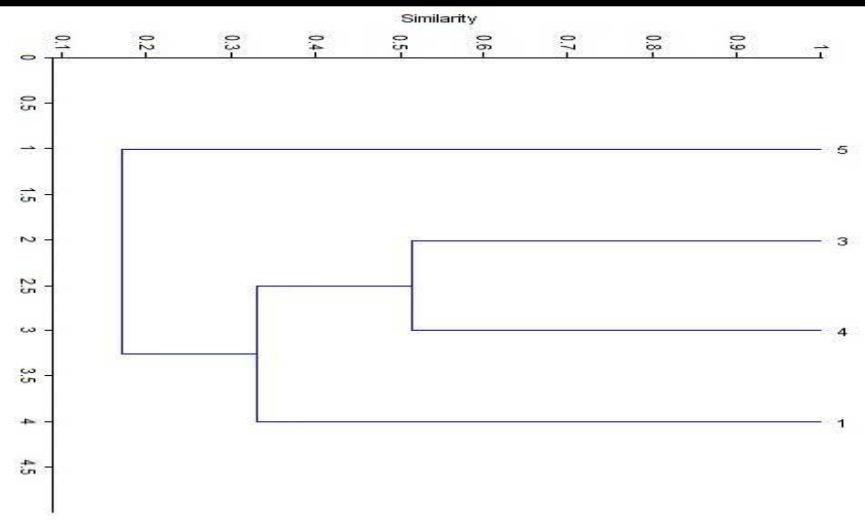

Fig. 2. Dendrogram of the four Carob genotypes as revealed by RAPD data.

\section{Conclusion}

Based on the results obtained for this study, it can be concluded that air layering is most suitable vegetative propagation technique for production of true to type plant of Carob compare to cuttings by using IBA at $8000 \mathrm{ppm}$ for genotype 3, 4, 5 and IBA at 6000 ppm for genotype 1 in May.

Some figures show the rooting in Carob seedlings by using vegetative propagation, air layering and stem cuttings: Fig 5. shows the well developed root after 30 days, Fig. 6 shows the well established Carob seedlings in plastic pot, Fig. 7 shows the air layer seedling after transferring to soil and Fig. 8 shows the well developed cuttings root after 60 days and established in plastic bag.

Egypt. J. Hort. Vol. 43, No.2 (2016) 


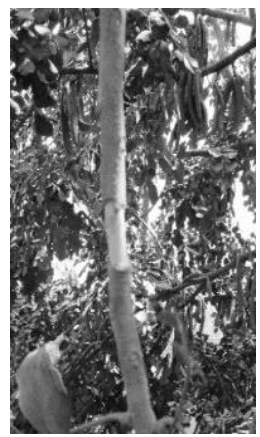

Fig. 3. Girdling by removing $3 \mathrm{~cm}$ in length.
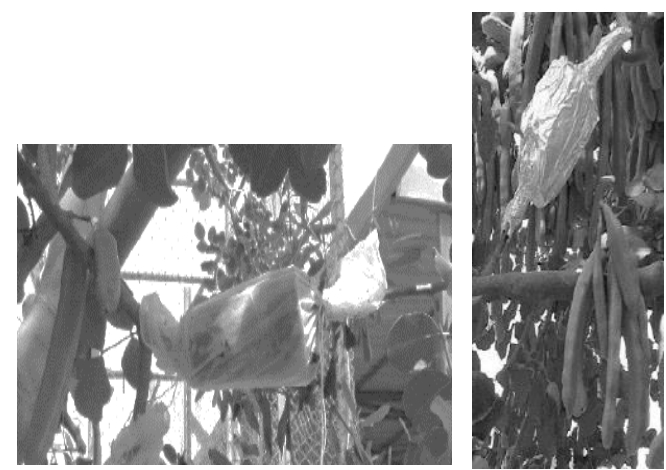

Fig. 4. Wrapped shoot with peat moss, bag and aluminum foil.
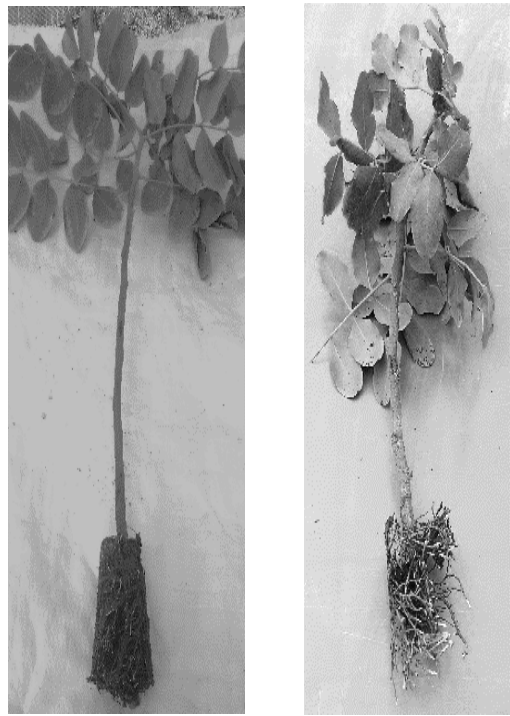

Fig. 5. Well developed air layer root.

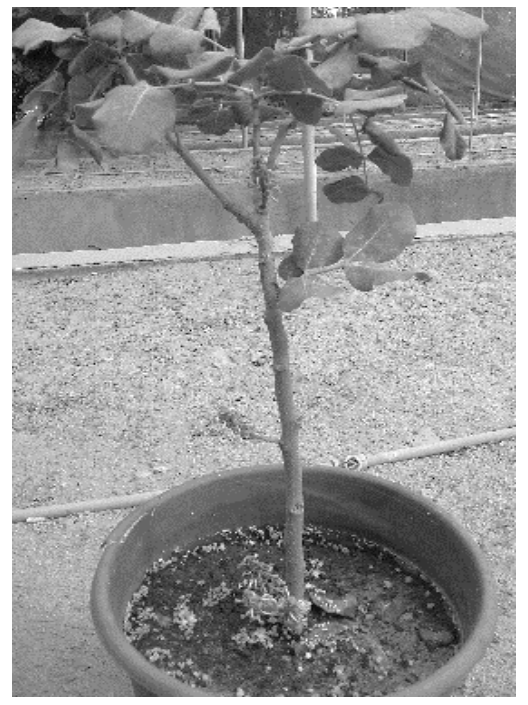

Fig. 6. Well established in plastic pot. 


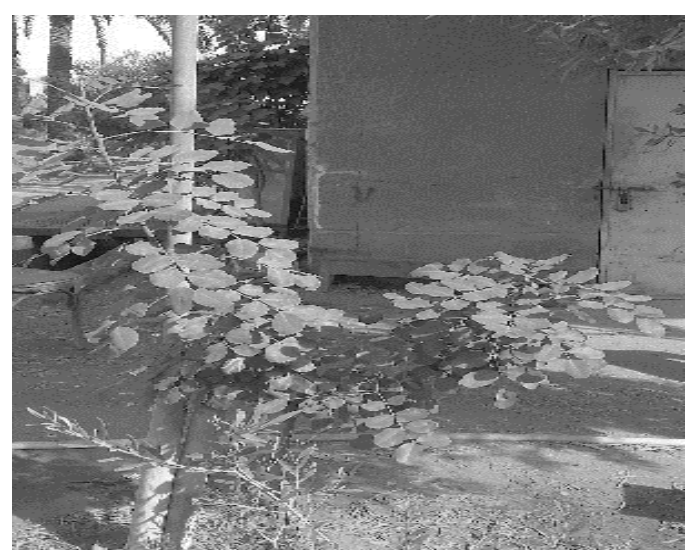

Fig.7. Air layer seedling after Transferring to soil.
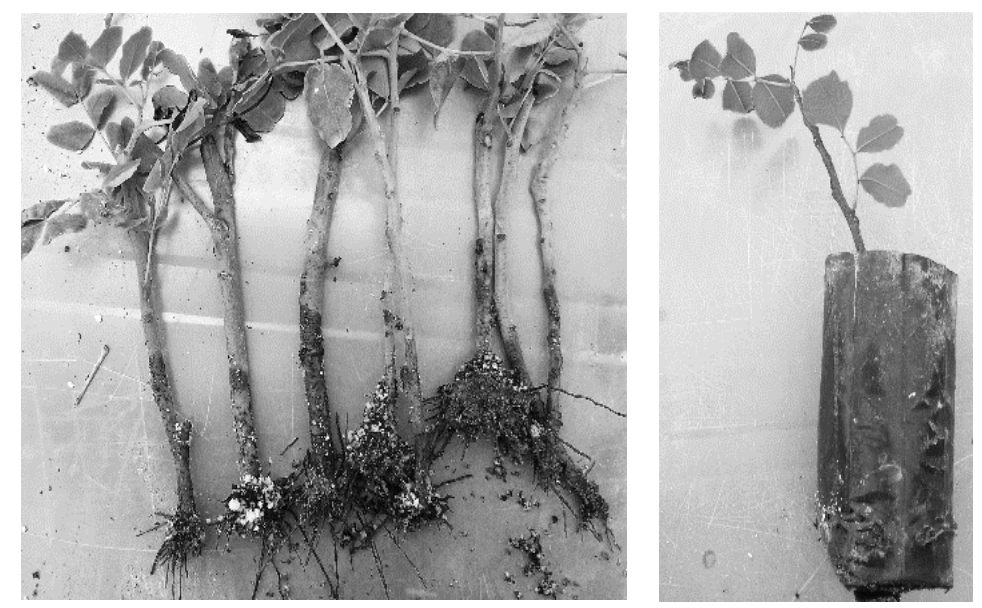

Fig.8. Well developed cutting root After 60 days and established in plastic Bag.

\section{References}

Al- Tury, M.H., Omari, M.A. and Abu Qaoud, H. (1999) Studies on the propagation of carob Ceratonia siliqua by stem cuttings. Dirasat, Agric. Sci., 25 (2), 161-167.

Batlle, I. and Tous, J. (1997) Carob tree (Ceratonia siliqua L.) Promoting the conservation and use of underutilized and neglected crops. 17. Institute of Plant Genetics and Crop Plant Research. Gatersleben /IPGRI, Rome, Italy. 
Biner, B., Gubbuk. H., Karhan, M., Aksu, M. and Pekmezci, M. (2007) Sugar profiles of the pods of cultivated and wild types of carob bean (Ceratonia siliqua L.) in Turkey. Food Chemistry, N100, pp.1453-1455.

Bora, N., Lal, R.L. and Singh. A.K. (2006) Effect of IBA and planting concentration on shoot and root characters and survival of litchi air layers. Indian J. Hort., 63 (2), 155 158 .

Chawla, W., Mehta, K. and Chauhan, N. (2012) Influence of plant growth regulators on rooting of litchi (Litchi chinensis Sonn) air layers. Asian J. Hort., 7 (1), 160- 164.

Crane, J.H. and Balerdi, C.F. (2008) Ackee growing in the Florida home landscape. Univ. of Florida. Original publication date.

Dakia, P.A., Wathelet. B and Paquot, M. (2007) Isolation and chemical evaluation of carob (Ceratonia siliqua L.) seed germ. food Chem., 102 (N4), 1368-1374.

Das, A.K. and Prasad, B. (2014) Effect of plant growth regulators on rooting survival of air layering in litchi. Advance Res. J. Crop Improve, 5 (2), 26-130.

Das, A.K., Singh, K.P., Kumar, R., Patel, B. and Ranjan, A. (2014) Response of bioregulators on air layering in litchi cv. Purbi. Asian J. Hort., 9 (2), pp 505- 506.

Duncan, D. B. (1955) Multiple ranges and multiple F test. Biometrics, 11, 1-24.

EL Kahkahi R., Moustaine M., Mouhajir A., Bachir S., Lemrhari A., Zouhair R., AIT Chitt M. and Errakhi R. (2016) Technical sheet on the culture carob tree (Ceratonia siliqua L.) in Morocco. https://hal.archives- ouvertes.fr/hal- 01319583

Gamlath, M., Abeywickrama, K. and Wickramarachchi, S. (2010) Root growth promotion of ficus species during air layering. Ceylon J. Sci., 39 (1), 45-51.

Gharnit, N., El Mtili, N., Ennabili, A. andSayah, F. (2004) Floral characterization of carob tree (Ceratonia siliqua $\mathrm{L}$ ) from the province of Chefchaouen (NW of Morocco). Moroccan J. Biol., 1, 1 -51.

Gubbuk, H., Gunes, E., Ayala-Silva, T. and Ercisli, S. (2011) Rapid vegetative propagation method for Carob. Not. Bot. Hort. Agrobot. Cluj., 39 (1), 251 -254.

Guzeldag, G. and Colak, O. (2007) Molecular identification of Ganoderm alucidum from Turkey. Int. J. Agric. Biol., 9, 767-770.

Hartmann, HT. and Kester, D.E. (1983) Plant Propagation, In: "Principles and Practices", $4^{\text {th }}$ ed., Prentice Hall, New York,USA, pp. 265-268.

Hess, C.E. (1962) Characterization of the rooting cofactor extracted from Hedera helix L. and Hibiscus Rosa-sinensis L. Proceeding of the $16^{\text {th }}$ int. Hort. Congress. pp 328- 388.

Janick, J. and Paul, R.E (2008) The Encyclopedia of Fruit and Nuts. CABI Publishing, $954 \mathrm{p}$. 
Laubscher, C.P. and Ndakidemi, P.A. (2008) The effect of indole acetic acid growth regulator and rooting medium on rooting of Leucadendron laxum (Proteaceae) in a shade tunnel environment. Am. Eurasian J. Agric. Environ. Sci., 4(3), 326-331.

Lee, CL., Paul, J.L and Hackett, W.P. (1977) Promoting of rooting in stem cuttings of several ornamental plants by pretreatment with acid or base. HortScience 12, 41-42

Lopes, R.L., Cavalcante, I.H.L., Oliveira, I.V.M, and Martins, A.B.G. (2005) Indole butyric acid levels on cashew cloning by air layering. process. Rev. Bras. Frutic., Jaboticabal, (27),3. p. $517-518$

Makris, D.P. and Kefalas, P. (2004) Carob pods (Ceratonia siliqua L.) as a source of poly phenolic antioxidants. Food Tech. and Biotec., 42, 105- 108.

Mohamed, A. I. S. (1980) Studies on carob propagation by cutting. PhD. Fac. Agric. Ain Shams Univ. Cairo, Egypt.

Morsy, A.A. (2007) Molecular variation of Achillea fragrantissima (Forssk.) SCH. BIP., growing in five areas of South Sinai. Int. J. Agric. Biol., 9, 11-17.

Pio, R., Dall-Orto, F.A.C., Alvarenga, A.A., Abrahao, E., Chagas, E.A. and Signorini, G. (2007) Propagation of Japones quince for cutting and air layering. Ciencia Agrotecnologia 31(2), 570-574.

Porebski, S., Bailey, L.G.and Baum, B.R. (1997) Modification of a CTAB DNA extraction protocol for plants containing high polysaccharide and polyphenol components. Plant. Mol. Biol. Rpt. 15, 8-15.

Romano, A., Barros. S. and Martins-Loucao M.A (2002) Micropropagation of the Mediterranean tree Ceratonia siliqua. Plant Cell Tissue Organ Culture, 68, 35-41.

Sasso, SAZ., Citadin, I. and Danner, MA. (2010) Propagation of Jabuticaba tree for grafting and air layering techniques. Revista Brasileira de Fruticultura. 32 (2), 571576.

Shaheen, S.A. and Aly, A.A. (2011) comparative studies on some factor affecting rooting ability of carob stem cutting. J. Amer. Sci. 7 (8), 285- 301.

Singh, P.T., Shukla, H.S. and Katiyar. P.N. (2009) Effect of indole butyric acid and phydroxybenzoic acid on regeneration of litchi cultivars through air layering. Ann Hort., 2 (2), 197-196.

Snedecor, G.W. and Cochran, W.G. (1980) "Statistical Methods", $7^{\text {th }}$ ed., Iowa State. Univ. Press, U.S.A. 593 p.

Talhouk, S.N., Breugel, P., Zurayk, R., Al-Khatib, A., Estephan, J., Ghalayini, A., Debian, N. and Lychaa, D., (2005) Status and prospects for the conservation of remant seminatural carob Ceratonia siliqua L. populations in Lebanon. Forest Ecol. Manage., 206, 49-59.

Yang, X. and C. Quiros, (1993) Identification and classification of celery cultivars with RAPD markers. Theor. Appl. Genet., 86, 205-212.

Egypt. J. Hort. Vol. 43, No.2 (2016) 
Zaen El-Deen, E.M., El-Sayed, O.M., El-Sayed, I. and Hegazi, G. (2014) Studies on carob (Ceratonia silique L.) propagation. IOSR J. of Agric. and Veterinary Sci., 7 (5), $31-40$

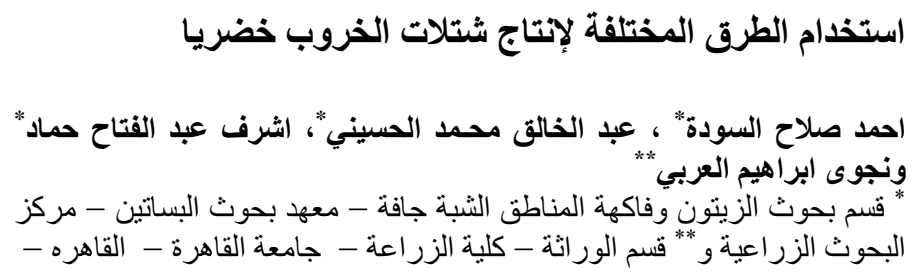

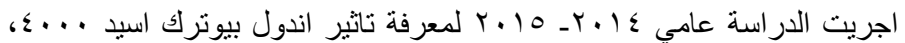

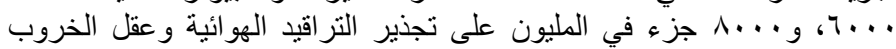

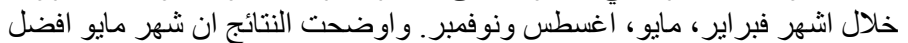

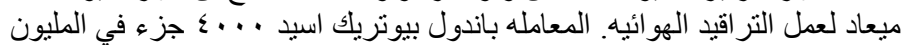

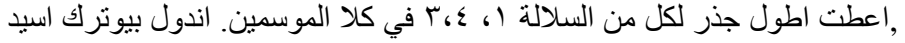

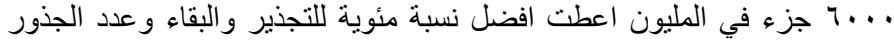

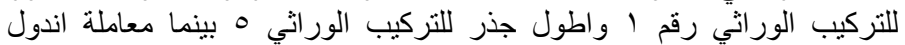

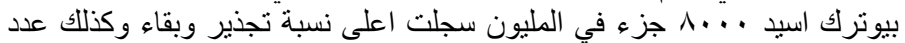

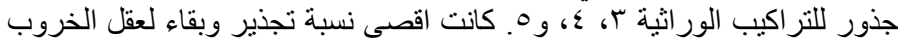

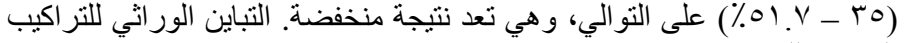

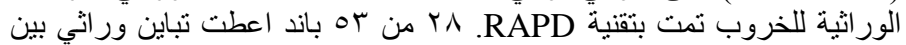

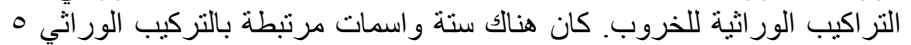

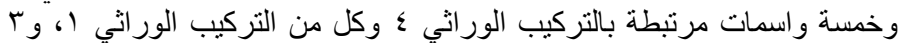
اعطى كلا منهم و اسماتين محددتين. 